\title{
Association of gestational age with the option of pregnancy termination for fetal abnormalities incompatible with neonatal survival
}

\author{
Associação da idade gestacional com a opção pela interrupção da gravidez de fetos \\ com anomalias incompatíveis com a sobrevida neonatal
}

Flavia Westphal ${ }^{1}$, Suzete Maria Fustinoni ${ }^{1}$, Vânia Lopes Pinto $^{1}$, Patrícia de Souza Melo ${ }^{1}$, Anelise Riedel Abrahão ${ }^{1}$

\section{ABSTRACT}

Objective: To identify the profile of women seen in a Fetal Medicine unit, diagnosed with fetal abnormality incompatible with neonatal survival in their current pregnancy, and to check the association of gestational age upon diagnosis with the option of pregnancy termination. Methods: This is a retrospective cohort study carried out in the Fetal Medicine Outpatients Clinic of a university hospital, in the city of São Paulo (SP), Brazil, using medical records of pregnant women with fetus presenting abnormalities incompatible with neonatal survival. The sample comprised 94 medical records. The Statistical Package for the Social Sciences (SPSS), version 19, was used for the data statistical analysis. Results: The population of the study included young adult women, who had complete or incomplete high school education, employed, with family income of one to three minimum wages, single, nonsmokers, who did not drink alcoholic beverages or used illicit drugs. Women with more advanced gestational age upon fetal diagnosis $(p=0.0066)$ and/or upon admission to the specialized unit $(p=0.0018)$ presented a lower percentage of termination of pregnancy. Conclusion: Due to characteristics different from those classically considered as of high gestational risk, these women might not be easily identified during the classification of gestational risk, what may contribute to a late diagnosis of fetal diseases. Early diagnosis enables access to specialized multiprofessional care in the proper time for couple's counseling on the possibility of requesting legal authorization for pregnancy termination.

Keywords: Congenital abnormalities; Fetal viability; Abortion, legal; Decision making

\section{RESUMO}

Objetivo: Identificar o perfil de mulheres atendidas em um serviço de Medicina Fetal, que receberam diagnóstico de anomalia fetal incompatível com a sobrevida neonatal na gestação atual, e verificar a associação da idade gestacional no diagnóstico com a opção pela interrupção da gravidez. Métodos: Trata-se de um estudo de coorte retrospectivo, realizado no ambulatório de Medicina Fetal de um hospital universitário da cidade de São Paulo (SP), com prontuários de mulheres com fetos portadores de anomalias incompatíveis com a sobrevida neonatal na gestação atual. A amostra constituiu-se de 94 prontuários. Para análise estatística dos dados, utilizou-se 0 programa Statistical Package for the Social Sciences (SPSS), versão 19. Resultados: A população foi de mulheres adultas jovens, com escolaridade compatível com o Ensino Médio completo/incompleto, empregadas, com renda familiar entre um e três salários mínimo, solteiras, que não faziam uso de tabaco, bebidas alcoólicas ou de drogas ilícitas. Verificou-se que mulheres com maior idade gestacional na ocasião do diagnóstico fetal $(p=0,0066)$ e/ou na chegada ao serviço especializado $(p=0,0018)$ apresentaram menor percentual de interrupção gestacional. Conclusão: Por apresentarem características diferentes daquelas classicamente consideradas de alto risco gestacional, é possível que essas mulheres não tenham sido facilmente identificadas durante a classificação de risco gestacional, 0 que pode ter colaborado para 0 diagnóstico tardio de patologias fetais. 0 diagnóstico precoce possibilita acesso à assistência multiprofissional especializada em tempo adequado para aconselhamento do casal sobre a possibilidade de solicitação de autorização judicial para a interrupção gestacional.

Descritores: Anormalidades congênitas; Viabilidade fetal; Aborto legal; Tomada de decisões

\footnotetext{
1 Universidade Federal de São Paulo, São Paulo, SP, Brazil.

Corresponding author: Flavia Westphal - Rua Napoleão de Barros, 754, room 312 - Vila Clementino - Zip code: 04024-000 - São Paulo, SP, Brazil - Phone: (55 11 ) $5576-4430$ extension:1654 E-mail: flavia_westphal@yahoo.com.br

Received on: Apr 24, 2016 - Accepted on: May 29, 2016

Conflict of interest: none.

DOI: 10.1590/S1679-45082016A03721
} 


\section{INTRODUCTION}

Congenital anomalies (CA), birth defects, congenital disorders, and congenital malformations are synonyms used to describe developmental disorders present at birth. They are consequences of failure of one or more body parts during the embryonic development; they can be structural, functional, metabolic, behavioral or hereditary. ${ }^{(1)}$ The defects may be present alone or in combination, comprising syndromes.

The etiology of CA may be related to genetic, environmental or multifactorial factors or remain unknown. It is estimated that 40 to $60 \%$ of all CAs have unknown cause. Among the known causes, the most common are multifactorial, related to combinations of genetic and environmental factors. ${ }^{(1,2)}$

The overall incidence of birth defects in Brazil is between 2 and $5 \%$ of all live births, not different from that found in other regions of the world. ${ }^{(3)}$

Mortality from CA affects children mainly in the first year of life. With the reduction of other causes of child mortality, such as diarrhea and respiratory infections, the percentage of deaths from malformations has become proportionally higher. In Brazil, CA rank second in cause of death of children. ${ }^{(4)}$

Congenital anomalies have great impact on the family and generate feelings of sadness for the loss of the idealized child, fear of the unknown, fear of difficulties to be faced, and a high risk of family breakdown. ${ }^{(2,5)}$

The diagnosis of a structural abnormality in the fetus enables antenatal counseling and planning of actions to be taken in the postnatal period. ${ }^{(6)}$

In order to improve the diagnostic approach of $\mathrm{CA}$, there has been a revolution in recent decades in the field of diagnostic imaging in obstetrics, providing images of the developing fetus, evaluation of growth and behavior, and increasingly earlier recognition of the abnormalities. Some examples of these technologies are two-dimensional and three-dimensional ultrasound, echocardiography, Doppler flowmetry and magnetic resonance, among otehrs. ${ }^{(7)}$

Along with the biotechnological evolution of fetal assessment, there was a breakthrough in genetics, with the development of molecular biology and the Human Genome Project, in which many diseases previously evaluated only in terms of statistical risk of occurrence and/or recurrence, are now diagnosed in-utero. ${ }^{(8)}$

Once the fetal diagnosis is established, in some cases, it is possible to propose alternative in-utero treatment, enabling better prognosis. However, for some fetal abnormalities that will lead to fetal death, the parents should be informed about the high risk of intrauterine, neonatal or infant death. Lethal fetal diseases, also described as nonviable or incompatible with neonatal survival, invariably lead to intrauterine fetal death or death in the neonatal period, regardless of attempting supportive measures or treatment. ${ }^{(5,9)}$

In these circumstances, in many parts of the world, such diagnoses are often followed by the couple deciding for abortion. ${ }^{(5,6)}$

In developed Western countries in Europe and North America, the termination of pregnancies in which the fetus has an anomaly incompatible with life is legal. ${ }^{(10,11)}$

In Brazil, the law only supports voluntary interruption of pregnancy in cases where the woman was victim of sexual violence, when the pregnancy is life-threatening for the mother, ${ }^{(4)}$ and, more recently, in the event of an unequivocal diagnosis of anencephaly. ${ }^{(12)}$

Women have therefore the legal right to decide whether to take forward or interrupt a pregnancy of an anencephalic fetus; nevertheless, this is not the only fetal anomaly incompatible with neonatal survival; there remains the concern about the outcome of other pregnancies, for which legal authorization is still required.

In face of a diagnosis of nonviable fetus, social and cultural aspects may interfere in the couple's decision. Therefore, specialized care and time for decision-making are key factors to prevent future mental disorders. ${ }^{(13)}$ Furthermore, maternal risks involved in continuing pregnancy should be considered and discussed with the parents, thus helping in the decision-making process of interrupting or not pregnancy. ${ }^{(6)}$

\section{OBJECTIVE}

To identify the profile of pregnant women with fetus presenting anomalies incompatible with neonatal survival, and to check whether gestational age influenced in the decision to request pregnancy interruption.

\section{METHODS}

A retrospective cohort study, conducted at the Fetal Medicine Outpatients Clinic - Universidade Federal de São Paulo (UNIFESP). Data collection was initiated after approval by the Internal Review Board of UNIFESP, protocol number 507.887, CAAE: 19093813.0.0000.5505. The coordinator signed the Terms of Data Collection Authorization for the Fetal Medicine Outpatients Clinic of UNIFESP. 
The population consisted of all records of women seen at the Fetal Medicine Outpatients Clinic-UNIFESP, from January $1^{\text {st }}, 2010$ to December $31^{\text {st }}$, 2013, who were diagnosed with fetal anomaly incompatible with neonatal survival in the current pregnancy, at any gestational age.

The fetuses were identified as unviable after evaluation by a team of specialized in fetal Medicine Physicians. Lethality was assumed in the presence of an anomaly or set of anomalies that would result in a likely intrauterine death, or if born live, in failure to independently survive without life support.

In cases established as nonviable, it was possible to request a court order for legal voluntary termination of pregnancy, when the couple so preferred. As from May 10, 2012, resolution 1989 provided for the legal termination of pregnancy in cases of anencephaly. ${ }^{(12)}$

The inclusion criterion was that the woman had received antenatal care of this pregnancy in this Outpatients Clinic until the outcome. Women were excluded if they were not enrolled, did not require hospitalization or those who did not undergo interruption or delivery in this unit.

Of the initial sample of 166 women with fetuses with lethal CA seen in our service, during the study period, 49 were excluded due to lack of records related to hospital admission for termination of pregnancy/ delivery; 14 because the records were not provided by the Medical Records and Statistics Service (SAME - Serviço de Arquivo Médico e Estatística), and 9 for not having registry in the Clinic. The final sample consisted of 94 medical records of women who received a diagnosis of fetal anomalies incompatible with neonatal survival in the current pregnancy.

The software used for data analysis was the Statistical Package for the Social Sciences (SPSS) version 19. Initially, we performed a descriptive study of the variables in the database. Continuous variables were analyzed by calculating mean, median, standard deviation, minimum and maximum. For categorical variables, frequency and percentage were calculated.

In order to compare categorical variables for interruption or continuation, we used the $\chi^{2}$ test and, whenever necessary, the odds ratio.

All analyzes were planned and developed taking into account a significance level of $5 \%(\mathrm{p}<0.05)$.

\section{RESULTS}

The sociodemographic characteristics are depicted on table 1, emphasizing the most frequent categories.

Of the records analyzed, $33 \%$ had one or more chronic diseases $(\mathrm{n}=31)$, the more prevalent being anemia $(22.6 \%)$, and hypertension (19.4\%).
Table 1. Distribution of women studied, according to sociodemographic data and habits

\begin{tabular}{lc}
\hline Characteristics & Total $(\mathbf{n = 9 4 )}$ \\
& $\mathbf{n}(\mathbf{\%})$ \\
\hline Age in years, mean \pm standard deviation & $28.46 \pm 7.15$ \\
White skin & $49(52.1)$ \\
Born in the Southeastern Region & $60(63.8)$ \\
Complete/incomplete High School & $51(54.3)$ \\
Catholic & $57(60.6)$ \\
Employed & $56(59.6)$ \\
Single & $55(58.5)$ \\
Lives with partner & $76(80.9)$ \\
Family income between 1 and 3 minimum wages & $48(51.1)$ \\
No smoking & $82(87.2)$ \\
No alcohol drinking & $67(71.3)$ \\
Never used illicit drugs & $83(88.3)$ \\
\hline
\end{tabular}

In $67 \%(n=63)$ of the records, registries on use of medication were found, in isolation or in combination, the more prevalent being vitamins (46\%), followed by analgesic agents (23.8\%), antibiotics (15.9\%), antihypertensive drugs $(7.9 \%)$, and antiemetic drugs $(1.6 \%)$.

In regards to obstetric history, the records indicated that women had a mean of 2.31 pregnancies and most of them had not planned the current pregnancy (73.4\%), as shown on table 2 .

Table 2. Distribution of women studied, according to obstetric history

\begin{tabular}{lc}
\hline Characteristics & $\begin{array}{c}\text { Total }(\mathbf{n}=\mathbf{9 4}) \\
\text { Mean } \pm \text { standard deviation }\end{array}$ \\
\hline Pregnancies & $2.31(1.38)$ \\
Parity & $0.88(1.14)$ \\
Abortions & $0.45(0.68)$ \\
Live births & $0.83(1.14)$ \\
Current pregnancy not planed & $69(73.4)$ \\
No fetus malformations in previous pregnancies & $89(94.7)$ \\
\hline
\end{tabular}

Most patients received fetal diagnosis (79.8\%) and/or came to the specialized clinic $(85.1 \%)$ only in the second trimester (from 14 weeks $1 / 7$ to 28 weeks). Only $8.5 \%$ $(n=8)$ of women were diagnosed with fetal anomalies incompatible with neonatal survival during the first trimester, as displayed on table 3.

Most women had no consanguineous partner (93.6\%) and no family history of CA $(85.1 \%)$.

Of the medical records studied, gestational interruption was conducted in $41(43.6 \%)$ cases and maintenance of pregnancy in $53(56.4 \%)$. 
Table 3. Distribution of women studied, according to characteristics related to fetal diagnosis

\begin{tabular}{lc}
\hline Characteristics & $\begin{array}{c}\text { Total (n=94) } \\
\mathbf{n}(\%)\end{array}$ \\
\hline Fetal disorder & $36(38.3)$ \\
Central nervous system & $20(21.3)$ \\
Genitourinary system & $18(19.1)$ \\
Chromosomal abnormalities & $9(9.6)$ \\
Thoraco-abdominal closing defect & $8(8.5)$ \\
Multiple malformations & $3(3.2)$ \\
Musculoskeletal system & \\
Gestational age upon fetal diagnosis & $8(8.5)$ \\
Up to 14 weeks & $48(51.1)$ \\
14 weeks $1 / 7$ to 21 weeks & $27(28.7)$ \\
21 weeks $1 / 7$ to 28 weeks & $11(11.7)$ \\
More than 28 weeks & \\
Gestational age upon first visit to the clinic & $3(3.2)$ \\
Up to 14 weeks & $41(43.6)$ \\
14 weeks $1 / 7$ to 21 weeks & $39(41.5)$ \\
21 weeks $1 / 7$ to 28 weeks & $11(11.7)$ \\
More than 28 weeks & \\
\hline
\end{tabular}

The more advanced the gestational age upon fetal diagnosis $(p=0.0066)$ and/or first visit to the specialized clinic $(p=0.0018)$, the lower the rate of request to interrupt pregnancy, as can be seen on table 4 .

Table 4. Characteristics related to fetal diagnosis of women studied, according to the choice of interrupting pregnancy

\begin{tabular}{|c|c|c|c|c|}
\hline \multirow[b]{2}{*}{ Variables } & \multicolumn{3}{|c|}{ Requested interruption } & \multirow[b]{2}{*}{ p value } \\
\hline & $\begin{array}{c}\text { Yes } \\
\text { n (\%) }\end{array}$ & $\begin{array}{c}\text { No } \\
\text { n (\%) }\end{array}$ & $\begin{array}{l}\text { Total } \\
\text { n (\%) }\end{array}$ & \\
\hline \multicolumn{5}{|c|}{ Gestational age upon fetal diagnosis } \\
\hline Up to 14 weeks & $6(75)$ & $2(25)$ & $8(100)$ & $0.0066^{*}$ \\
\hline 14 weeks $1 / 7$ to 21 weeks & $26(54.2)$ & $22(45.8)$ & $48(100)$ & \\
\hline 21 weeks $1 / 7$ to 28 to weeks & $7(25.9)$ & $20(74.1)$ & $27(100)$ & \\
\hline More than 28 weeks & $2(18.2)$ & $9(81.8)$ & $11(100)$ & \\
\hline Total & $41(43.6)$ & $53(56.4)$ & $94(100)$ & \\
\hline \multicolumn{5}{|c|}{ Gestational age upon first visit to the clinic } \\
\hline Up to 21 weeks & $27(61.4)$ & $17(38.6)$ & $44(100)$ & $0.0018^{* *}$ \\
\hline 21 weeks $1 / 7$ to 28 weeks & $13(33.3)$ & $26(66.7)$ & $39(100)$ & \\
\hline More than 28 weeks & $1(9.1)$ & $10(90.9)$ & $11(100)$ & \\
\hline Total & $41(43.6)$ & $53(56.4)$ & $94(100)$ & \\
\hline
\end{tabular}

\section{DISCUSSION}

This study comprised a population of young adult pregnant women with schooling level of complete/ incomplete High School, employed, with family income between one and three minimum wages, single but living with a partner. More than half of them were born in the Southeastern region (63.8\%), as expected, since the clinic is located in the city of São Paulo.

The mean age was 28.46 years, or less, younger than the age classically considered at risk for development of fetal anomalies. Another study conducted in São Paulo with pregnant women and fetuses with lethal malformation found similar results, with a mean age of 25 years. $^{(14)}$

Most of the study population did not use tobacco $(87.2 \%)$, alcoholic beverages $(71.3 \%)$ or illicit drugs $(88.3 \%)$. These data, contrary to expected, revealed a population with different characteristics from those considered as high-risk pregnancy, and similar to those of pregnant women in general..$^{(15)}$ Thus, it is noteworthy the fact that these women probably started their antenatal care at a low risk service, and were not easily identified during the gestational risk classification, which may have contributed to late diagnosis of fetal disease.

In this study, alcohol was used by a minority of pregnant women, but its teratogenic potential was highlighted. Alcohol intake during pregnancy has been identified for decades as responsible for the occurrence of fetal abnormalities, and the current consensus is that there is no safe limit of intake during pregnancy. ${ }^{(16)}$

Alcohol is a known teratogen that poses a severe risk for development of the fetal central nervous system. Its chronic consumption in high doses is associated with fetal alcohol syndrome, but moderate use also has some effects, including permanent neurobehavioral disorders. ${ }^{(17)}$

Although the population includes young adult pregnant women, $33 \%$ of them had chronic diseases, and anemia and hypertension were the most frequently reported. Moreover, $67 \%(n=63)$ of pregnant women used medications. Maternal anemia is associated with increased rates of maternal and fetal mortality and infectious diseases, as well as increased risk of prematurity and low birth weight. Furthermore, one of the causes may be folate deficiency, which is associated with increased risk of neural tube closing defects during pregnancy. ${ }^{(18)}$

As for hypertension in pregnancy, if medication is used, the adequacy of the previously used drugs should be taken into account, since some antihypertensive agents, such as angiotensin-converting enzyme inhibitors and angiotensin receptor blockers, are contraindicated because of their teratogenic potential. ${ }^{(15,17)}$

The teratogenic potential of exposing pregnant women to certain medications is already known and has been widely studied. In 1982, the Food and Drug 
Administration (FDA) established five categories (A, $\mathrm{B}, \mathrm{C}, \mathrm{D}$ and $\mathrm{X}$ ) to indicate the teratogenic potential of each drug. ${ }^{(19)}$

In this study, the most prevalent drug class was vitamins. Despite being considered a specific medication by the Brazilian National Health Surveillance Agency (ANVISA), ${ }^{(20)}$ vitamins are classified as category A, according to the risk of teratogenicity proposed by the FDA, that is, they do not have teratogenic potential. However, excluding the use of vitamins, we found exposure to drugs of other therapeutic classes in $53.2 \%$ $(n=50)$ of the women studied.

In a study in the city of Maringa (PR), with records of malformed fetuses, exposure to drugs during pregnancy was observed in $63.2 \%$ of records. Of these, $51.5 \%$ were drugs classified in the categories $\mathrm{B}, \mathrm{C}$, and $\mathrm{D}$, as proposed by the FDA, and $12.1 \%$ in Category $\mathrm{X}$, considered of high teratogenic risk. This study concluded that the occurrence of CA may be related to substance use during pregnancy, given the high percentage of drugs used with high teratogenic risk. ${ }^{(21)}$

Considering the problem of alcohol, tobacco, and medication consumption by women, the Ministry of Health established some specific actions to be taken on the preconception phase, as described on the Manual for Low Risk Antenatal Care, published in 2012. However, very few women seek this care, since most pregnancies are unplanned. ${ }^{(15)}$

Gestational planning, or lack of it, is worth analyzing, since in unplanned pregnancy the woman may have contact with teratogenic agents without concern, because the possibility of pregnancy is not considered.

In this study, we observed most women $(73.4 \%)$ had not planned the current pregnancy, a fact confirmed by other investigations, which found that the majority of the population that seeks public antenatal services does not plan pregnancy. ${ }^{(22)}$

Furthermore, due to non-gestational planning, very few women have the opportunity of receiving a preconception evaluation to investigate current and previous health problems that may interfere in the normal progress of a future pregnancy. The possibility of changing treatment to medications with less teratogenic potential and better clinical control of existing chronic diseases should also be considered, providing better maternal and perinatal outcomes. ${ }^{(15)}$

In relation to gestational age at the first visit to the clinic, according to the medical records most women were admitted in the second trimester; $43.6 \%$ with a gestational age of $141 / 7$ weeks to 21 weeks, and $41.5 \%$ with gestational age of 21 weeks $1 / 7$ to 28 weeks. Most often, it was at this moment that the antenatal diagnosis of fetal CA incompatible with neonatal survival was made. We observed that only a small portion of pregnant women received a diagnosis of fetal anomalies incompatible with neonatal survival during the first trimester, and the percentage of those attending the reference service in that period was even lower (3.2\%). This scenario is similar to those found in a study carried out in the same department, with data from women seen between 2000 to 2006, where the diagnosis of fetal anomaly incompatible with neonatal survival was made up to the $13^{\text {th }}$ week in only $17 \%$ of pregnancies. ${ }^{(9)}$

Although the Ministry of Health recommends only one obstetric ultrasound during pregnancy, and does not consider it a mandatory exam for low-risk pregnancies, ${ }^{(15)}$ it is known that this exam is a critical tool in the diagnosis of developmental anomalies for screening fetal morphology, placenta and amniotic fluid. ${ }^{(23)}$

A study conducted with pregnant women seen in primary care in the city of Goiania (GO) showed that only $41.8 \%$ of them had one obstetric ultrasound per trimester of pregnancy. ${ }^{(24)}$ A national hospitalbased investigation, including postpartum women and newborns, demonstrated that although the majority of women (98.2\%) referred having had an antenatal ultrasound, the report was available only in part of the prenatal cards analyzed $(62.8 \%)$. From the records available, we found that only a quarter of the exams was performed before the $14^{\text {th }}$ gestational week, when it is better to calculate gestational age. This calculus is essential to monitor the course of pregnancy and any decisions related to its termination. ${ }^{(25)}$

The results showed that the more advanced the gestational age upon diagnosis $(p=0.0066)$, and the gestational age on first visit to the clinic $(p=0.0018)$, the lower the percentage of request for termination of pregnancy.

We therefore noted that pregnant women faced difficulties to have access to diagnosis of fetal anomaly, as well as to be referred to the specialized clinic. As a consequence, part of them received late specialized care and definite diagnosis of fetal malformation.

A study on factors that influenced the decisions of maintaining pregnancy after diagnosis of a lethal perinatal condition reported the gestational age upon diagnosis did not influence the decision-making. ${ }^{(26)}$ However, study of fetuses with heart disease found that gestational age upon diagnosis was a major factor for the parents to make decision for termination of pregnancy $(<0.001)$. $^{(27)}$

Maternal-fetal attachment increases with gestational age, particularly after experiencing the first fetal 
movements. ${ }^{(28)}$ This leads us to infer that the more advanced the pregnancy, the greater the involvement of pregnant women with the fetus, and the harder the decision to terminate pregnancy.

\section{CONCLUSION}

The population studied had different characteristics from those considered as high-risk pregnancy. Hence, it is possible that these women will not be easily identified during the gestational risk classification, which may contribute to late diagnosis of fetal diseases. Therefore, all women, regardless of risk factors, should have guaranteed a morphological ultrasound during the first trimester, preferably between the $11^{\text {th }}$ and $13^{\text {th }}$ week of pregnancy.

The more advanced the gestational age upon diagnosis and at the first visit to the clinic, the lower the percentage of requests to interrupt pregnancy.

Early diagnosis of fetal disease provides access to specialized multidisciplinary care in adequate time to counsel the couple about the possibility of judicial authorization request for termination of pregnancy.

\section{REFERENCES}

1. Sadler TW. Langman embriologia médica. 12a ed. Rio de Janeiro: Guanabara Koogan; 2013.

2. Calone A, Madi JM, Araújo BF, Zatti H, Madi SR, Lorencetti J, et al. Malformações congênitas: aspectos maternos e perinatais. Rev AMRIGS. 2009; 53(3):226-30.

3. Nhoncanse GC, Melo DG. [Reliability of birth certificates as a source of information on congenital defects in the City of São Carlos, São Paulo, Brazill. Cienc Saude Colet. 2012;17(4):955-63. Portuguese.

4. Victora CG, Aquino EM, do Carmo Leal M, Monteiro CA, Barros FC, Szwarcwald $\mathrm{CL}$. Maternal and child health in Brazil: progress and challenges. Lancet. 2011;377(9780):1863-76.

5. Wilkinson DJ, Thiele P, Watkins A, De Crespigny L. Fatally flawed? A review and ethical analysis of lethal congenital malformations. BJOG. 2012;119(11): 1302-8. Review.

6. Breeze $A C$, Lees CC. Antenatal diagnosis and management of life-limiting conditions. Semin Fetal Neonat Med. 2013;18(2):68-75. Review.

7. Araujo Júnior $E$, Nardozza LM, Moron AF. Ultrassonografia $3 D$ em obstetrícia. Barueri: Manole; 2011. [Série Educação Continuada em Obstetrícia].

8. Walters L. Genetics and bioethics: how our thinking has changed since 1969. Theor Med Bioeth. 2012;33(1):83-95.

9. Sala DC, Abrahão AR. Complicações obstétricas em gestações com feto portador de anomalia incompatível com a sobrevida neonatal. Acta Paul Enferm. 2010; 23(5):614-8

10. Nash E, Gold RB, Rowan A, Rathbun G, Vierboom Y. Laws affecting reproductive health and rights: 2013 state policy review [Internet]. New York: Guttmacher
Institute; 2013 [cited 2015 Ago 22]. Available from: http://www.guttmacher. org/statecenter/updates/2013/statetrends42013.html

11. Dommergues M, Mandelbrot L, Mahieu-Caputo D, Boudjema N, DurandZaleski I; ICI Group-Club de médicine foetale. Termination of pregnancy following prenatal diagnosis in France: how severe are the foetal anomalies? Prenat Diagn. 2010;30(6):531-9.

12. Brasil. Conselho Federal de Medicina. Resolução CFM no 1.989/2012. Dispõe sobre o diagnóstico de anencefalia para a antecipação terapêutica do parto e dá outras providências [Internet]. Diário Oficial da República Federativa do Brasil Brasília (DF); 2012 Maio 14; Seção I, p. 308-9 [citado 2016 Maio 23]. Disponível em: http://www.portalmedico.org.br/resolucoes/CFM/ 2012/ 1989 2012.pdf

13. Abrahão AR. Gestação de fetos anencéfalos: fatores de risco, diagnóstico situacional e impacto da assistência interdisciplinar [tese]. São Paulo: Escola Paulista de Medicina, Universidade Federal de São Paulo; 2000.

14. Benute GR, Nomura RM, Lucia MC, Zugaib M. Interrupção da gestação após o diagnóstico de malformação fetal letal: aspectos emocionais. Rev Bras Ginecol Obstet. 2006;28(1):10-7.

15. Brasil. Ministério da Saúde. Secretaria de Atenção à Saúde. Departamento de Atenção Básica. Atenção ao pré-natal de baixo risco. Brasília (DF): Ministério da Saúde; 2012. [Série A. Normas e Manuais Técnicos]. [Cadernos de Atenção Básica, n- 32]

16. Zanoti-Jeronymo DV, Nicolau JF, Botti ML, Soares LG. Repercussões do consumo de álcool na gestação - estudo dos efeitos no feto. Braz J Surg Clin Res. 2014;6(3):40-6.

17. Schüler-Faccini L, Sansaverino MT, Abeche AM, Vianna FS, Silva AA. Manual de teratogênese em humanos. Rio de Janeiro: FEBRASGO; 2011.

18. US Department of Health and Human Services. The health consequences of smoking-50 years of progress: a report of the surgeon general [Internet]. Atlanta (GA): US Department of Health and Human Services, Centers for Disease Control and Prevention, National Center for Chronic Disease Prevention and Health Promotion, Office on Smoking and Health; 2014 [cited 2016 May 23] Available from: http://ash.org/wp-content/uploads/2014/01/full-report.pdf

19. Pregnancy categories prescription drugs. FDA Drug Bull. 1982;12(3):24-5.

20. Agência Nacional de Vigilância Sanitária (ANVISA). Perguntas frequentes/ Medicamentos. Medicamentos específicos [Internet]. Brasília (DF): ANVISA; 2005-2009 [citado 2015 Ago 22]. Disponível em: http://portal.anvisa.gov. $\mathrm{br} / \mathrm{wps} /$ content/anvisa + portal/anvisa/perguntas + frequentes/medicament os/3c08f70040507035a91ca989c90d54b4 http://portal.anvisa.gov.br/web/ ggmed/medicamentos-especificos 1

21. Ramos WL, Benevento CE, Malgarin J, Stefanello TF, Ramos ER. Análise do uso de medicamentos durante a gestação em mães de pacientes portadores de malformações fetais. Rev Saúde e Pesquisa. 2008;1(1):59-64.

22. Borges AL, Cavalhieri FB, Hoga LA, Fujimori E, Barbosa LR. Pregnancy planning: prevalence and associated aspects. Rev Esc Enferm USP. 2011;45(Spec 2): 1679-84.

23. Conner SN, Longman RE, Cahill AG. The role of ultrasound in the diagnosis of fetal genetic syndromes. Best Pract Res Clin Obstet Gynaecol. 2014;28(3): 417-28. Review.

24. Devers PL, Cronister A, Ormond KE, Facio F, Brasington CK, Flodman P. Noninvasive prenatal testing/noninvasive prenatal diagnosis: the position of the National Society of Genetic Counselors. J Genet Couns. 2013;22(3):291-5.

25. Lo JO, Cori DF, Norton ME, Caughey AB. Noninvasive prenatal testing. Obstet Gynecol Surv. 2014;69(2):89-99.

26. Hassed SJ, Miller CH, Pope SK, Murphy P, Quirk JG Jr, Cunniff C. Perinatal lethal conditions: the effect of diagnosis on decision making. Obstet Gynecol. 1993;82(1):37-42.

27. Chenni N, Lacroze V, Pouet C, Fraisse A, Kreitmann B, Gamerre M, et al. Fetal heart disease and interruption of pregnancy: factors influencing the parental decision-making process. Prenat Diagn. 2012;32(2):168-72.

28. Gomez R, Leal I. Vinculação parental durante a gravidez: versão portuguesa da forma materna e paterna da Antenatal Emotional Attachment Scale. Psico Saude Doenças. 2007:8(2);153-65. 